Vysoce vyzdvihnout je třeba práci autorů knihy s osobním fondem profesora Kosteletzkého. Přinesla nesčetné poznatky o jeho způsobu práce se studenty, o systému, který použival při výuce botaniky apod. Podrobné informace o aktivitách ve spojení s botanickou zahradou však samožrejmě najdeme i u dalších vyučujících. Text jde místy i do naturalistických pasáží, když např. na s. 36 uvádí podmínky při práci v zahradě, která sloužila z nedostatku jiných prostor i pro výuku mediků, pro anatomii. „Posluchárna farmaceutické chemie byla skutečným dřevníkem, kde mrtvolný zápach a při děláni preparátio také uhelné plyny a kouř nás mučil, kde nám sedmi až devíti posluchačům v zimě zamrzával inkoust $v$ kalamářrich a umrzaly nehty na nohou v botách.“ nebo „Nauka o svalstvu přednášela se v měsíci lednu. Mrtvoly se uživalo přibližně šest týdnů, takže pak už docela zezelenaly."1

Rozsáhlost a podrobnost textu vede k tomu, že některá tvrzení se opakují, najdeme pasáže, které nezapadají úplně logicky do textu (např. mezi s. 56 a 58), což je daň podrobnému výzkumu a snaze po detailní přesnosti tvrzení. Nepřesné je např. tvrzení na s. 82 (pozn. 293), že Ignác Nádherný byl studijním ředitelem univerzity, ačkoli toto označení je třeba omezit jen na lékařská studia. Na s. 155 najdeme zmínku o Boženě a Ferdinandovi Náprstkových. Jde samozřejmě o bratra Vojty Náprstka, ten ale užíval německou formu př́jmení Fingerhut. Z dalších drobných nepřesností se tu sluší uvést, že (s. 226 v pozn. 603) Výbor pro př́rodovědecký výzkum Čech (dosavadní literatura se drží původního názvu komitét pro př́rodovědecký výzkum Čech) neinicioval Jan Palacký, který se na jeho práci podílel jen velmi okrajově, ale roku 1864 Jan Evangelista Purkyně spolu s Karlem Kořistkou, Janem Krejčím a dalšími prrírodovědci, jako základ Purkyní zamýšlené akademie.

Kniha je honosně vypravena i po technické stránce - kvalitní a četná obrazová dokumentace jí dodává lesk. Není to však čtení do kabelky vzhledem k váze kvalitního papíru a desek. Jako celek kniha představuje značný krok vpřed v poznání výuky př́rodovědným předmětům na pražské univerzitě v 19 . a první polovině 20 . století a př́klad skvělé práce s historickými prameny.

Milada Sekyrková doi: $10.14712 / 23365730.2019 .12$

\title{
Ewa Dziurzyńska - Martina Šumová (eds.), Korespondencja Adama Vetulaniego z Miroslavem Boháčkiem
}

Kraków, Polska Akademia Umiejętności - Archiwum Nauki PAN i PAU - Masarykủv ústav a Archiv Akademie věd ČR, v. v. i., 2017, 234 s., ISBN 978-83-7676-103-9

Edice korespondence právních historiků Adama Vetulaniho (1901-1976) a Miroslava Boháčka (1899-1982) vstupuje do značné míry na pole neorané - dost výrazně totiž překračuje cézuru roku 1948 a její převažující část spadá do let šedesátých. V dosavadních edicích korespondence mezi českými (resp. československými) a polskými vědci byla tato chronologická hranice překročena jen málokdy; jedná se o historii dosud do značné míry „živou“. Tedy nejen obrazně, ale i v tom smyslu, že ještě žijí pamětníci - spolupracovníci (a v př́padě Adama Vetulaniho také mladší žáci) hlavních protagonistů knihy.

1 Citát převzat z publikace Ludmila KratochvílovÁ-HlaváčKovÁ, Jan Theobald Held 1770-1851, Praha 1972. 
Publikace je dalším z výsledků dnes již letité spolupráce mezi Masarykovým ústavem Archivem Akademie věd ČR a Archiwum Nauki Polskiej Akademii Nauk i Polskiej Akademii Umiejętności v Krakowie. Svou grafickou podobou a edičními zásadami navazuje na jeden z předchozích výsledků uvedené spolupráce, edici korespondence orientalisty Tadeusze Kowalského s jeho pražskými kolegy Janem Rypkou a Bedřichem Hrozným. Obě knihy spojuje také osoba polské editorky a redaktorky publikace Ewy Dziurzyńské, spolupracující tentokrát na české straně s autorkou řady prací o M. Boháčkovi Martinou Šumovou.

Celý soubor korespondence zahrnuje 96 dopisů a korespondenčních lístků či pohlednic z let 1956-1975. Jedná se o soubor velmi dobře dochovaný, přičemž významnou část ztrát originálů $\mathrm{v}$ osobním fondu adresáta bylo možné doplnit díky existenci strojopisných kopií na průklepovém papíŕe $\mathrm{z}$ fondu odesílatele. Listy jsou v edici řazeny chronologicky a doplněny podrobnými věcnými a textologickými vysvětlivkami v poznámkách pod čarou; využitelnost výrazně zvyšuje osobní rejstř́k. Úvodní studie a ediční poznámka jsou vedle češtiny a polštiny přeloženy do angličtiny. Bohatá je také obrazová př́iloha.

Pro dějiny vysokého školství jsou editované prameny důležité nejen jako výpověd’ o česko-polských kontaktech $\mathrm{v}$ oblasti dějin práva (zejména římského a církevního) a kodikologie, ale také jako zajímavý komparativní materiál k profesnímu životu a každodennosti dvou vědeckých osobností stejného věku a oboru ve dvou různých zemích východního bloku. $\mathrm{V}$ obou prípadech se jednalo o univerzitní profesory právnických fakult postižené komunistickým režimem, ale zatímco Adam Vetulani směl nadále učit, Miroslav Boháček nalezl útočiště v Komisi pro studium a soupis rukopisů a jejích dalších metamorfózách. Uvolnění poměrů v Polsku po roce 1956 a v Československu zhruba od počátku 60. let inspirovalo k jejich živější spolupráci, která měla i svůj mezinárodní rozměr v podobě možnosti publikovat zejména v Itálii a Německu. S možnostmi výjezdů do západní Evropy už to bylo horší.

Pro dějiny pražské univerzity (a dokonce př́mo pro počátky časopisu AUC-HUCP) je korespondence mezi A. Vetulanim a $\mathrm{M}$. Boháčkem rovněž mimořádně zajímavý pramen. Ukazuje totiž, jak se odborný zájem obou právních historikủ na přelomu 50. a 60. let postupně přesouval od jiných témat $\mathrm{k}$ počátkům středoevropských univerzit. Této problematice věnovali řadu studií, jejichž vznik i související výměnu informací je možné v korespondenci podrobně sledovat (a díky podrobným vysvětlivkám se rychle zorientovat $\mathrm{v}$ kontextu). Zmiňme tedy alespoň Boháčkovu studii o založení a nejstarší organizaci pražské univerzity (AUC-HUCP VI/1, 1965) a Vetulaniho populárně-vědnou syntézu „Początki najstarszych wszechnic środkowoeuropejskich“(Wrocław - Warszawa - Kraków 1970). Dodejme ještě, že A. Vetulani má své místo i v meziválečných dějinách pražské univerzity, protože byl jedním z polských stipendistů, kteří navštívili její právnickou fakultu (byt' na krátkou dobu dvou týdnů v první polovině listopadu 1925).

Z řady výše uvedených důvodů můžeme vydání edice v podobě čtenářum tak př́ivětivé jen přivítat a prát si, aby byly podobnou formou editovány i další významné soubory česko(-slovensko)-polské vědecké korespondence. Tato podoba zpř́stupnění totiž umožňuje číst korespondenci jako celek a intenzivně vnímat vzájemnou interakci obou stran, v tomto př́padě např́íklad v oblasti nezištných odborných konzultací a inspirací pro vznik zásadních děl k nejstarším dějinám středoevropských univerzit. 